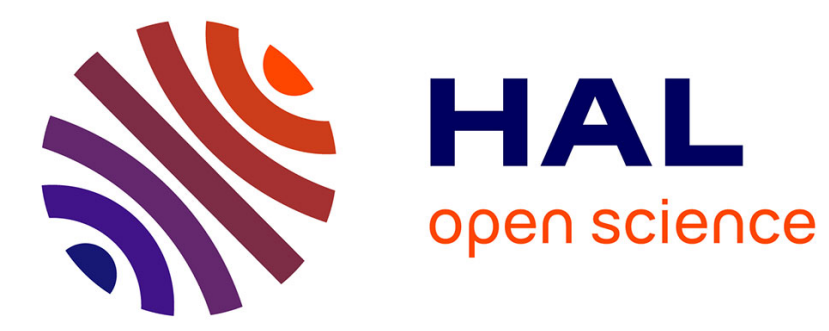

\title{
Thermocouple Junctioned with Ferrites
}

\author{
O. Kwon, Y. Fukushima, M. Sugimoto, N. Hiratsuka
}

\section{To cite this version:}

O. Kwon, Y. Fukushima, M. Sugimoto, N. Hiratsuka. Thermocouple Junctioned with Ferrites. Journal de Physique IV Proceedings, 1997, 07 (C1), pp.C1-165-C1-166. 10.1051/jp4:1997160 . jpa-00255107

\section{HAL Id: jpa-00255107 https://hal.science/jpa-00255107}

Submitted on 1 Jan 1997

HAL is a multi-disciplinary open access archive for the deposit and dissemination of scientific research documents, whether they are published or not. The documents may come from teaching and research institutions in France or abroad, or from public or private research centers.
L'archive ouverte pluridisciplinaire HAL, est destinée au dépôt et à la diffusion de documents scientifiques de niveau recherche, publiés ou non, émanant des établissements d'enseignement et de recherche français ou étrangers, des laboratoires publics ou privés. 


\title{
Thermocouple Junctioned with Ferrites
}

\author{
O.H. Kwon, Y. Fukushima, M. Sugimoto and N. Hiratsuka* \\ Teikyou Heisei University, Ichihara-city, Chiba-Prefecture, Japan \\ * Saitama University, Shimo Ohkubo, Urawa-city, Japan
}

\begin{abstract}
Measurements are reported of the thermo-e.m.f. of a thermoelectric junction composed of polycrystalline ferrites or multilayered ferrite films as a function of the temperature. The thermo-e.m.f. of the bulk and ferrite films was much larger than that of the conventional thermoelectric junction made of metals. A positive or negative thermoelectric power was observed depending on the difference in the combination of ferrites. The temperature dependence was almost linear from room temperature up to about $500^{\circ} \mathrm{C}$ and above which it showed a tendency to saturate. Application of a magnetic field had a reducing effect upon the thermo-e.m.f. at temperature of room to the Curie temperature.
\end{abstract}

\section{INTRODUCTION}

Studies on thermoelectric properties and thermoelectric energy conversion technology are being made very actively by many researchers for chalcogenides, silicate, borate, rare earth compounds and some oxides of $\operatorname{In}_{2} \mathrm{O}_{3}$ and $\mathrm{SnO}_{2}$. Only a few reports on ferrites, however, have been published to date and research data on the thermal properties of ferrites are there still remains a number of unclarified point. Ravinder et al. [1] have reported that Seebeck coefficients of the mixed $\mathrm{Mn}-\mathrm{Zn}$ ferrites are negative and the values decrease with the increase of zinc concentration. Ratil et al.[2] measured the variation of Seebeck coefficient with temperature for $\mathrm{Cd}_{0.3} \mathrm{NiO}_{0.7-\mathrm{x}} \mathrm{Mn}_{\mathrm{x}} \mathrm{Fe}_{2-2 \mathrm{x}} \mathrm{O}_{4}$ system and found that the coefficient changes from negative to positive depending on the $n$ - or p-type ferrite which is related to the Mn-values.

Through the examination of the above-mentioned investigations, we had a great interest in the Seebeck coefficients of ferrites which are much larger than that of metal or alloy and we have tried to apply the large value, which is characteristic of ferrites, to a practical use. In the present paper we report the measurement of thermo-e.m.f. of thermoelectric junctions formed from polycrystalline ferrites or multilayered ferrite films and then discuss the observed results.

\section{EXPERIMENTAL}

Polycrystalline samples of spinel ferrite; such as $\mathrm{Li}, \mathrm{Cu}, \mathrm{Mn}, \mathrm{Ni}, \mathrm{Cu}-\mathrm{Zn}, \mathrm{Mn}-\mathrm{Zn}$ and $\mathrm{Ni}-\mathrm{Zn}$ ferrite, with dimensions of about $5 \times 5 \times 20 \mathrm{~mm}$ were prepared by the conventional sintering method. An end of a couple of ferrite bars was mechanically contacted with each other and placed into a small electric furnace. The other detached two ends of ferrite bars were closely connected to Pt wires respectively by use of a conductive paste and then jointed them to an electric circuit where the thermal-e.m.f. is to be measured.

Ferrite films were prepared on a quartz glass plate by the sputtering method. Two layers of ferrite film are placed one on top of each other as shown in Fig.1. The film thickness was in the range from 5000 to $10000 \AA$. The measuring method was the same as that of the polycrystalline specimen.

\section{RESULTS AND DISCUSSION}

Fig.2 shows the variation of thermo-e.m.f. with temperature for thermoelectric junctions formed from the combination of $\mathrm{Mn}$ and $\mathrm{Ni}, \mathrm{Mn}$ and $\mathrm{Mn}-\mathrm{Zn}$ and also $\mathrm{Cu}$ and $\mathrm{Cu}-\mathrm{Zn}$ polycrystalline ferrite. From this figure it is 
observed that the thermo-e.m.f. has positive or negative values depending on the difference in the constituent ferrites. For the combination of $\mathrm{Mn}$ and $\mathrm{Ni}$ ferrite, the thermoelectric powers are positive throughout the measured temperature range. A negative thermoelectric power is observed for the thermoelectric junctions made from the combination of $\mathrm{Mn}$ and $\mathrm{Mn}-\mathrm{Zn}$ as well as $\mathrm{Cu}$ and $\mathrm{Cu}-\mathrm{Zn}$ ferrite. The sign of thermal-e.m.f. may be due to a hopping process between $\mathrm{Mn}$ ions or $\mathrm{Cu}$ ions in the two constituent ferrites.

Fig.3 shows the variation of thermal-e.m.f. of a thermal electric junction consisting of multilayered films of $\mathrm{Ni}$ and Co ferrite as a function of the temperature. A negative thermo-e.m.f. is found to decrease with temperature up to about $500^{\circ} \mathrm{C}$ and above which it shows a tendency to saturate. This may perhaps be due to the structual peculiarities of the ferrites.

\section{CONCLUSION}

The following conclusions can be drown:

1. The Thermo-e.m.f. of a thermoelectric junction formed from polycrystalline ferrites or multilayered ferrite films is much larger than that of metals or alloys.

2. The sign of positive or negative in thermo-e.m.f. is dependent on the difference in the combination of a couple of ferrites.

3. The thermo-e.m.f. of thermoelectric ferrite junction has a tendency to saturate at temperatures beyond $500^{\circ} \mathrm{C}$.

\section{References}

[1] D.Ravinder and K.Latha, J.Appl. Phys. Vol.75, pp.6118-6120 (1994).

[2] M.G.Patil, V.C.Mahajan, B.V.Bhise, S.M.Chendke and S-A.Patil, Phys. Stat. Vol.144 pp.415-419 (1994)

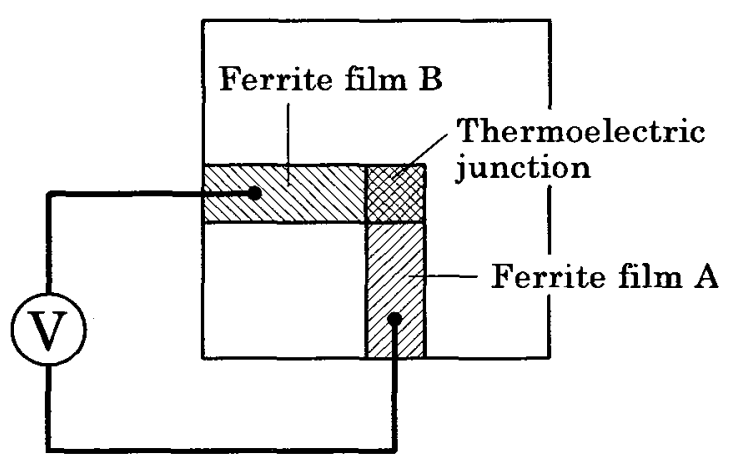

Fig.1 A schematic diagram of thermoelectric junction composed of multilayered ferrite films.
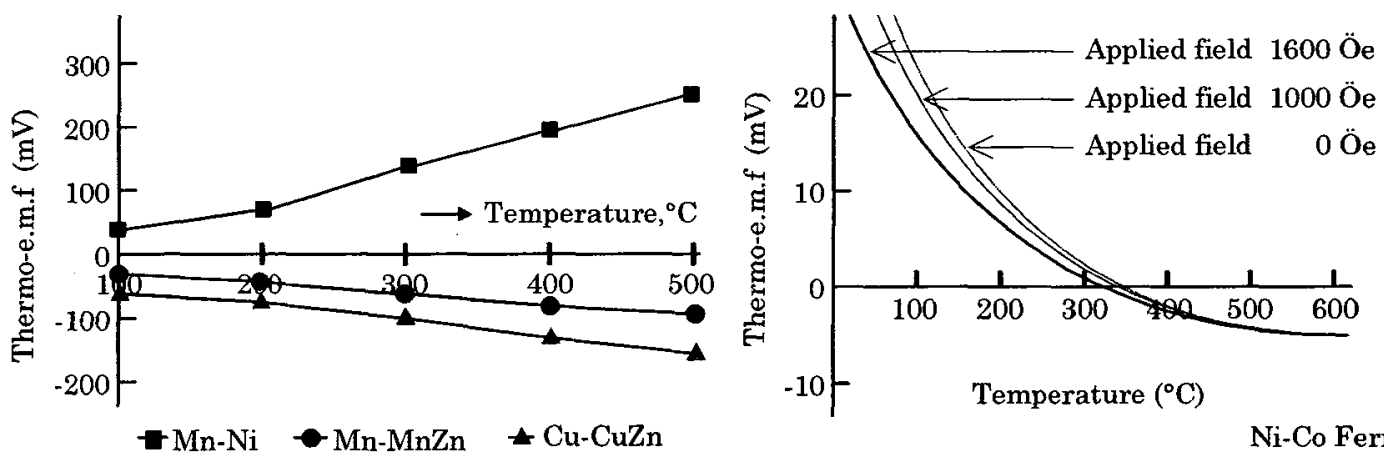

Fig.2 Variation of thermo-e.m.f. of thermoelectric junction made from polycrystalline ferrite bars as a function of the temperature.

Fig.3 Thermoelectric power of thermoelectric junction formed from multilayered ferrites. 